\title{
HALYNA KOVAL'CHUK
}

\section{BIBLIOLOGY IN MODERN UKRAINE: THE MAIN TRENDS, SCIENTIFIC SCHOOLS, TENDENCIES}

The foundations of bibliology as an academic discipline. The role of bibliological journals and multi-author publications. Research centres, research directions, research achievements. The significance of research into history of book culture.

KEY WORDS: Ukrainian bibliology, bibliologic schools, book monument studies, history of book culture, rare books expertise

In recent decades bibliology in Ukraine, as well as in other countries, has undergone significant transformations, primarily due to the rapid development of mass media, especially the incredibly fast increasing number of electronic resources. These processes are objective but the traditional paper book with printed text remains. Oddly enough, the number of publication titles is growing despite a perceptible tendency of decreasing book editions. This process must be studied, analysed and predicted, while providing proper conclusions to the publishing industry. However, the colossal quantity of books accumulated in libraries, archives, museums and private collections remains the main interest of bibliology.

Thus, bibliology is alive and the reflection of its development in Ukraine can be observed particularly in the following examples: the existence of the speciality "Bibliology, Library Science, Bibliography" for the defence of dissertations. Since 1997 this speciality code was 07.00 .08 (historical, philological, pedagogical sciences) and since 2011 the code is 27.00 .03 (social communica- 
tion, historical sciences). Dissertation research was conducted (by L. Lytvynova, ${ }^{1}$ O. Pastushen $\mathrm{ko}^{2}$ ) in which the topics, essence and statistics of defended dissertations were considered and analysed. Thus, it is possible to make a selection of bibliological problems that were submitted for defence, and attest the priority of certain issues. At the same time, the review of dissertations showed that the fundamental issues of the theory and methodology of books and bibliology were not the constant objects of the researchers' attention.

The periodicals in the field (scientific collections and journals) indicate the existence of bibliological research. Until recently, the number of publications which were approved by the Ministry of Education and Science of Ukraine as specialised in the field of bibliology, library science and bibliography, was quite sufficient. The Vernadsky National Library of Ukraine ${ }^{3}$ (hereinafter — VNLU) for many years has been publishing the journal "Library Journal" (6 issues per year), periodical collections "Academic Papers of VNLU", "Manuscript and Book Heritage of Ukraine", "Libraries of National Academies of Sciences: problems of functioning, tendencies of development". The Ivan Fedorov Book Chamber of Ukraine publishes the monthly "The Journal Bulletin of the Book Chamber". The National Academy of Culture and Arts Management publishes the journal "Library Science. Document Studies. Informology" (4 issues per year). "Bulletin of Kharkiv State Academy of Design and Arts" has been published 4 times per year since 1999. The yearbook "Visnyk of Lviv University. Series: Bibliology, Library Studies and Information Technologies" was published from 2006 to 2017. Odessa National University, named after I.I. Mechnikov, has been publishing a similar periodical "Journal of Odessa National University. Series: Library Science, bibliography, bibliology" since 2007. In 2019 it was renamed "Library Mercury". The annual journal "Proceedings of Vasyl Stefanyk National Scientific Library of Ukraine in Lviv" has been published since 2008. "Scientific works of the V.O. Sukhomlynskyi State Scientific and Pedagogical Library of Ukraine" has been published twice a year since 2008. "Scientific works of Ivan Ohienko Kamianets-Podilskyi National University. Series: Library Science. Book science" has been published with the same frequency since 2008.

${ }^{1}$ L. A. Lytvynova, Dysertatsiyni doslidzhennya yak dzherelo vyznachennya stanu i tendentsiy rozvytku knyhoznavstva, bibliotekoznavstva, bibliohrafoznavstva v Ukrayini (1994-2012). Avtoreferat dyssertatsyy... kandydata nauk iz sotsial'nykh komunikatsiy, Kyyiv 2013.

2 O. V. Pastushenko, Knyha i periodyka $v$ dysertatsiynykh doslidzhennyakh nezalezhnoyi Ukrayiny. Sotsiokomunikatsiynyy aspekt. Monohrafiya, Kyyiv 2016; idem, Knyha i periodyka vdysertatsiynykh doslidzhennyakh nezalezhnoyi Ukrayiny. Sotsiokomunikatsiynyy aspekt. Avtoreferat dyssertatsyy... doktora nauk iz sotsial'nykh komunikatsiy, Kyyiv 2016.

3 See: http://nbuv.gov.ua/node/626. 
Bibliology is traditionally taught in higher educational institutions of culture, publishing and printing, at the faculties of journalism, at the departments of library science and bibliography, as well as library science and informology of a number of universities: Ivan Franko National University of Lviv, Rivne State Humanitarian University, Borys Grinchenko Kyiv University, and others. Thereafter, numerous materials are prepared and published by academics: manuals (by M. Nyzovy, ${ }_{4}^{4}$ G. Shvetsova-Vodka, ${ }^{5}$ N. Chernysh,${ }^{6}$ O. Karakoz ${ }^{7}$, discipline programmes arranged by V. Medvedeva, I. Tymoshenko, L. Zelenska, M. Makarova, L. Syrota, M. Zhenchenko, V. Kudlai, G. Borodina and others. They differ depending on the author's understanding of bibliology, the specifics and specialisation of higher education institutions, the number of hours and so on. In most cases, bibliology as a discipline is called "Bibliography" or "General Bibliography" and only in the manual of the Lviv Ukrainian Academy of Printing is it called "Fundamentals of Bibliology". The author of the publication is N.I. Chernysh and she uses the term 'bibliology' as a synonym of the term 'bibliography'. It is important to add that theologians use the term 'bibliology' while referring to a set of knowledge about the Bible, ${ }^{8}$ which sometimes leads to confusion. Naturally, academic disciplines are based on scientific research conducted by bibliologists and reflect it to a certain extent. Let us attempt to determine the main directions of such research.

Firstly, there are terminological and theoretical studies that consider bibliology a science, with its subject and structure, as well as the book a phenomenon. Amongst the relevant modern referential and encyclopaedic articles we shall name our own publications ${ }^{9}$ which contain a generalised understanding of bibliology, European origins of bibliographic scientific knowledge, stages of Ukrainian bibliology, its main features and traditions, ${ }^{10}$ definition of the book itself as the

4 M. A. Nyzovyy, Vstup do knyhoznavstva. Navchal'nyy posibnyk, Kyyiv 2009.

5 G. M. Shvetsova-Vodka, Obshchaya teoriya dokumenta i knigi. Uchebnoye posobiye, Moskva-Kyev 2009; eadem, Zahal'na teoriya dokumenta i knyhy. Navchal'nyy posibnyk, Kyyiv 2014.

6 N. I. Chernysh, Osnovy bibliolohiyi. Navchal'nyy posibnyk, Kyyiv 2014.

7 O. O. Karakoz, Knyhoznavstvo. Praktykum, Kyyiv 2017.

${ }^{8}$ See e.g.: V. A. Mitskevich, Bibliologiya, http://www.blagovestnik.org/books/00225.htm.

9 H. Koval'chuk, "Knyhoznavstvo", [in:] Spetsial'ni istorychni dystsypliny. Dovidnyk, ed. I. N. Voytsekhivs'ka, Kyyiv 2008, pp. 308-316; eadem, "Knyhoznavstvo”, [in:] Ukrayins'ka arkhivna entsyklopediya, ed. I. B. Matyash, Kyyiv 2008, pp. 513-514; eadem, "Knyhoznavstvo ta doslidzhennya istoriyi knyhy v Ukrayini”, [in:] Entsyklopediya istoriyi Ukrayiny, vol. 4, ed. V. A. Smoliy, Kyyiv 2007, pp. 362-363; eadem, "Knyhoznavstvo", [in:] Entsyklopediya suchasnoyi Ukrayiny, vol. 13, Kyyiv 2013, pp. 377-379; eadem, "Knyhoznavstvo", [in:] Ukrayins'ka bibliotechna entsyklopediya, http://surl.li/oojh; eadem, "Knyhoznavstvo", [in:] Knyhoznavcha shkola. Antolohiya, comp. V. M. Medvedyeva, Kyyiv 2016.

10 G. I. Koval'chuk, "Istoricheskiye traditsii ukrainskoy knizhnoy kul'tury i ikh issledovaniya", [in:] Kniga. Issledovaniya i materialy, vol. 89, nr 1-2, Moskva 2002, pp. 80-92. 
main subject of research, ${ }^{11}$ consideration of the historical path and prospects for its further development, presented in a concise way and adapted to the profile of issuings. We also co-authored a Dictionary of bibliographic terms (2003), added dictionaries of historical and bibliographic terms to our own publications: the monograph Book records (rare and valuable books) in library collections (2004, pp. 541-637) and manual Manuscripts and Old Prints (2011, pp. 80-93); participated in assembling of the dictionary of the electronic library encyclopaedia, ${ }^{12}$ particularly the block of bibliological terms.

Among Ukrainian scholars engaged in the theory of bibliology, we should first mention the works of Doctor of Historical Sciences, Professor of Rivne State University of Humanities, Galyna Shvetsova-Vodka. Her concept of bibliology can be called documentary. According to the theory of social information communication she primarily considers the book as a type of document. In the above-mentioned publication General theory of document and book, she gave a definition of a book according to the features of the material carrier of information, sign form and ways of human perception of the book; determined the place of the book in the social communication and information process, the relation between the book and documents, the concepts of 'document', 'book', 'publication', and 'literature'. Moreover, she compared functions and properties of the document and the book. As was the case in the other publications, this author paid considerable attention to the concept of the typology of the book, methods of typological knowledge, its main categories and principles. The concept of 'types and genres of literature' is also defined by the author; the classification of publications is made.

G.M. Shvetsova-Vodka is the author of many articles on both documentary and bibliological topics. The titles of the articles indicate the subject of the author's research. After the discussion with Russian bibliologists, who according to the scientist, understand the term bibliology too narrowly (only as a publishing business, its history, as well as book distribution) and have replaced one of the objects of bibliology - the book business, with the ambiguous concept of 'book culture', Shvetsova-Vodka suggests (in the article "Current problems of bibliology"13) to replace the term 'book science' with the more common 'bibliology', and use the term 'bibliosophy' for the theory of bibliology. It should be recalled that these terms were introduced into science a century ago but for various reasons, primarily ideological, were rejected in the Soviet Union. According to the author, the following theoretical problems of bibliology remain unsolved: the definition of the

11 H. Koval'chuk, "Knyha, Knyzhka”, [in:] Ukrayins'ka bibliotechna entsyklopediya, http:// surl.li/ooiy.

12 Ukrayins'ka bibliotechna entsyklopediya, http://ube.nlu.org.ua/.

13 H. M. Shvetsova-Vodka, "Aktual'ni problemy bibliolohiyi”, Visnyk Knyzhkovoyi palaty 2013, no 9, pp. 40-41. 
book as the main bibliological category, the status of the e-book, terminology, particularly the names of some bibliological disciplines, and the place of bibliology in the system of scientific knowledge, especially its relationship with documentology.

These problems are also examined by G.M. Shvetsova-Vodka in other publications, in particular: "The place of bibliology in the system of scientific knowledge", 14 "Bibliological research of book culture", 15 "Teaching bibliology in Ukraine", 16 "New definitions of the category "the book", 17 "Modern state and development prospects of bibliology as a complex science devoted to book culture" ${ }^{18}$ etc. In all the scientist's publications is noted the documentary approach for the solution of the current problems of bibliology and bibliography; however, mainly the achievements of Russian bibliology are analysed.

The socio-communicative direction of bibliological research is presented by the scientific school of the Kharkiv State Academy of Culture. ${ }^{19}$ Amongst the brightest works in this area are Victoria Markova's monograph ${ }^{20}$ and doctoral dissertation Book communication: theory, history, development prospects (2011). The evolution of the structure of book communication and functions of its main components (the author, the reader, intermediaries) are considered here. The scientist argues that throughout its history, book communication has been formed as a system of institutions responsible for the creation and distribution of socially significant information. Book communication has always been perceived as an important factor of civilisational progress, the spiritual and intellectual development of society. The last few decades have become a testing time for book communication. The spread of new methods of mass communication is often perceived as

14 Eadem, "Mistse bibliolohiyi v systemi naukovoho znannya", Bibliotechnyy visnyk 2013, no 4, pp. 3-9.

${ }^{15}$ Eadem, "Bibliologicheskiye issledovaniya knizhnoy kul'tury", [in:] Sovremennyye problemy knizhnoy kul'tury. Osnovnyye tendentsii i perspektivy razvitiya. Materialy Mezhdunarodnogo nauchnogo seminara (Minsk, 2-3 aprelya 2014 g.), Minsk-Moskva 2014, pp. 59-62.

16 Eadem, "Prepodavaniye bibliologii v Ukraine", [in:] Berkovskiye chteniya - 2015. Knizhnaya kul'tura $v$ kontekste mezhdunarodnykh kontaktov. Materialy III Mezhdunarodnoy nauchnoy konferentsii (Minsk, 26-27 maya 2015 g.), Minsk-Moskva 2015, pp. 599-603.

17 Eadem, "Novyye opredeleniya kategorii »kniga«", [in:] Sovremennyye problemy knizhnoy kul'tury. Osnovnyye tendentsii i perespektivy razvitiya. Materialy III i IV Mezhdunarodnykh seminarov, Minsk-Moskva 2015, pp. 121-126.

18 Eadem, "Sovremennoye sostoyaniye i perspektivy razvitiya bibliologii kak kompleksnoy nauki, posvyashchennoy knizhnoy kul'ture", [in:] Knizhnaya kul'tura. Opyt proshlogo i problemy sovremennosti, Moskva 2015, pp. 388-392.

19 V. Sheyko, N. Kushnarenko, A. Solyanyk, "Kharkivs'ka naukova shkola knyhoznavstva, bibliotekoznavstva ta bibliohrafoznavstva: systema komunikatsiynykh zv"yazkiv", Visnyk Knyzhkovoyi palaty 2012, no 11, pp. 40-45.

20 V. A. Markova, Knyha v sotsial'no-komunikatyvnomu prostori. Mynule, suchasne, maybutnye. Monohrafiya, Kharkiv 2010. 
a threat to the existence of the book. The author notes that postmodernist concepts, which question the key ideas of book communication, have become an ideological danger to the implementation of its functions. These processes have caused a crisis of book communication due to the fact that the book as a complex phenomenon, combining spiritual and material components, has traditionally been the basic object of bibliological research. In addition, the author claims that book communication is a unique subsystem of social communications, which implements the selection of information based on value traits; therefore overcoming technical, social and psychological barriers of the message coming from the author to the reader is only possible under conditions of interaction between the book and electronic communications.

V. Markova has addressed the same issues of the book communication history, theory and future in a number of articles: "Study of book communication: a semiotic approach"; 21 "The book in the context of the socio-communicative approach: achievements and prospects" 22 (the assignment of the communicative channel place to the book is explained here); "Methodological principles of studying book communication". ${ }^{23}$ The author claims that a comprehensive study of book communication should be based on the meta-theory of social communication and bibliological concepts.

V. Markova studies the correspondence between the traditional paper book and e-book, ${ }^{24}$ in particular how a printed book forms the perception and representation of reality and how this capacity differs from the e-book. ${ }^{25}$ Without denying the benefits of the e-book, the author offers to see what society will lose with the disappearance of the traditional book as a unique means of communication. She proves that despite the development of new information technologies, the traditional book has not lost its significance. In addition, it has a number of advantages over the electronic version as it contains information perceivable without intermediaries. It is established that book communication is able to integrate into a new electronic communication range, while actively influencing the configuration of other social communication types due to its unique communicative

${ }^{21}$ Eadem, "Doslidzhennya knyzhkovoyi komunikatsiyi. Semiotychnyy pidkhid", Visnyk Kharkivs'koyi derzhavnoyi akademiyi kul'tury 41, 2013, pp. 187-196.

${ }^{22}$ Eadem, "Knyha v konteksti sotsial'no-komunikatyvnoho pidkhodu. Zdobutky ta perspektywy", Polihrafiya i vydavnycha sprava 2008, no 1, pp. 73-79.

${ }^{23}$ Eadem, "Metodolohichni zasady vyvchennya knyzhkovoyi komunikatsiyi", Visnyk Knyzhkovoyi palaty 2014, no 2, pp. 42-44.

24 Eadem, "Prohnoz shchodo maybutn'oho knyhy", Visnyk Kharkivs'koyi derzhavnoyi akademiyi kul'tury 32, 2011, pp. 207-215; eadem, "Knyzhkova y elektronna komunikatsiyi. Problemy vzayemovplyvu", Visnyk Kharkivs"koyi derzhavnoyi akademiyi kul'tury 45, 2014, pp. 70-78.

25 Eadem, "Knyha yak sotsial'no-komunikatyvna model' spryynyattya y reprezentatsiyi real'nosti", Visnyk Knyzhkovoyi palaty 12, 2010, pp. 35-38. 
properties. Electronic communication imitates the book's communication and due to the better availability of referenced sources, it significantly expands the possibilities of obtaining information. The presentation of texts has been gradually changing under the influence of book communication, using its main features, eliminating the flaws related to the inconvenience of reading from a screen. After all, the most indisputable reason for the advantage of a traditional book is the inconvenience of reading electronic texts: reading from a screen quickly tires the eyes, it is also impossible to read using a computer while being in bed or on the road. Nonetheless, the development of special reading instruments has somewhat removed these limitations; moreover, the appearance of these tools increasingly resembles a traditional book. Nowadays they have binding and pages (instead of a monitor 'scroll') and letters appear with the help of 'electronic ink' on 'electronic paper'. It is indicative that such book terminology is used. Apart from the theoretical course of bibliological research, the historical one must be distinguished. Foremost, it is about studying the history of Ukrainian bibliology as a science. An adequate retrospective review was made by Academician Y.D. Isayevych. ${ }^{26}$ M.T. Andriychuk ${ }^{27}$ has analysed four stages of historical and bibliological studies of the 19th-early 21 st centuries (the 19 th-early 20 th century is the interwar period, the late 1950s-early 1990s is the period of independence of Ukraine). We as well considered the historical path of Ukrainian bibliology against the background of the European one. ${ }^{28}$ N.M. Shalashna considered in a number of articles ${ }^{29}$ and in her dissertation (2004), a development of historical and bibliological thought in Ukraine in the 19th century. We analysed the history of Ukrainian bibliology from 1917 to the mid-1930s, particularly the activities of the Ukrainian Scientific Institute of Bibliology (USIB, 1922-1936), in a series of articles and a monograph. ${ }^{30}$ It was a period of rapid development of Ukrainian bibliology: a powerful school of bibliology was established, which specialised in the study of history and art of domestic books, the study of book sociology, the 'book-reader' complex, as well as the scientific basis of a Ukrainian bibliological repository, including periodicals from the Ukrainian library census (conducted by means of questionnaires). The

26 Ya. D. Isayevych, “Ukrayins'ke knyhoznavstvo. Etapy rozvytku”, Visnyk L'vivs'koho universytetu. Seriya knyhoznavstvo, bibliotekoznavstvo ta informatsiyni tekhnolohiyi 1, 2006, pp. 7-19.

${ }^{27}$ M. T. Andriychuk, "Z istoriyi stanovlennya vitchyznyanoyi knyhoznavchoyi nauky (XIX-pochatok XXI st.)", Tekhnolohiya i tekhnika drukarstva 2016, no 4, pp. 88-111; 2017, no 1, pp. $88-103$.

28 H. Koval'chuk, "Knyhoznavstvo", [in:] Spetsial'ni istorychni dystsypliny..., pp. 308-316.

29 N. Shalashna, "Istoriya knyhy yak nauka v pershiy polovyni XIX st.", Naukovi pratsi Natsional'noyi biblioteky Ukrayiny imeni V. I. Vernads'koho 10, 2003, s. 42-60; eadem, "Osoblyvosti rozvytku istoryko-knyhoznavchoyi dumky v Ukrayini v druhiy polovyni XIX st.", Naukovi pratsi Natsional'noyi biblioteky Ukrayiny imeni V. I. Vernads'koho 11, 2003, pp. 398-426.

${ }^{30}$ H. I. Koval'chuk, Ukrayins'kyy naukovyy instytut knyhoznavstva (1922-1936), Kyyiv 2015. 
works of foreign authors on the state of the book business and bibliology in other countries were published in the USIB journal Bibliological News. This journal was well known in Europe, particularly in Poland and Czechoslovakia, due to its correspondents. At the same time, the national originality of Ukrainian bibliology put it on a par with world scientific thought.

However, the period of fruitful development of Ukrainian bibliology was quite short. The demands of quick practical results, attempts of restructuring bibliology on the principles of Marxism, and the search for class enemies within bibliology led to the defeat and destruction of bibliological institutions, individual bibliologists and bibliology as a science. From the second half of the 1930s to the end of the 1950s, bibliology did not exist in the USSR, especially in Ukraine.

The gradual revival of bibliology in Ukraine is reviewed in a number of articles by various authors, firstly by I.V. Tymoshenko. ${ }^{31}$ It is obvious that the study of the historical retrospective of book science is a fruitful area of research, as without the established knowledge of predecessors, it is impossible to develop new fields. Since the 1990s bibliological research in Ukraine has been gaining momentum, judging by the results we have mentioned at the beginning of the article and others, such as: teaching bibliology in higher education institutions, the emergence of professional periodicals and collections, scientific conferences and bibliological readings, a corresponding increase in publications, issuing of scientific catalogues with a powerful bibliological component, and also monographs. According to O.V. Pastushenko, during the period from 1992 to 2015 there were 84 dissertations defended on the discipline of 'bibliology, library science, bibliography' in Ukraine. They were devoted to the book and book culture. Five of them are doctoral and hold great value for the theory, history and historiography of bibliology. ${ }^{32}$

It should be emphasised that a characteristic feature of modern Ukrainian bibliology is the institutionalisation of new bibliological disciplines based on practical work with books, as theory sprouts from practice. Bibliology is a theoretical science. However, without the study of specific books, certain groups of books, types of publications, large or small collections, especially historical, bibliology is doomed. Its place within the system of public communications will be taken by other scientific disciplines, which will study different types of information, information carriers and its various forms.

Among such theoretical disciplines directly related to the practice of researching specific books, we would like to single out codicology as a science that studies manuscript codices, and codicography as a special historical discipline that stud-

31 I. V. Tymoshenko, Ukrayins'ke knyhoznavstvo u 60-70-kh rokakh XX st., Bibliotechnyy visnyk 2008, no 5, pp. 17-23.

32 O. V. Pastushenko, Knyha i periodyka $v$ dysertatsiynykh doslidzhennyakh nezalezhnoyi Ukrayiny. Sotsiokomunikatsiynyy aspekt. Monohrafiya, Kyyiv 2016. 
ies a systematic description of manuscripts (codices) as historical sources. Terminological and theoretical principles of codicology and codicography as scientific disciplines were developed by L.A. Dubrovina ${ }^{33}$ (head of the VNLU manuscript department at that time) and for almost 30 years this codicological scientific school has been a leader in Ukraine. Ukrainian manuscripts were fruitfully studied by Y.P. Zapasko. ${ }^{34}$ Moreover, they are actively researched by V.Y. Frys, ${ }^{35}$ a scientist from the Manuscript Department of the Vasyl Stefanyk Lviv National Scientific Library.

Throughout history, books have been actively studied, mostly by the staff of rare books departments in large libraries (old prints, rare and valuable publications). In general, the history of the book was and is the most popular bibliological scientific discipline. In our opinion, it is necessary to study not only the history of book publishing, but also the whole complex of scientific knowledge and practical activities related to book memorabilia, i.e. books that are monumental for mankind's history and culture. We are talking about a wide range of questions involving the history of the book, starting with the process of publisher's choice of author, his work, the choice of liturgical or simply religious text, a classic work of antiquity; identification of fashion for specific works or genres of literature during a certain era. A printing characteristic of a particular publishing house is necessary (font, placement on the strip; decorations, book formats, design of the title information), as well as analysis of the publications design (the use of different printing techniques, the work of prominent artists and engravers, interpretation of artistic level and symbolism). But today it is just as important to study the history of a certain book in society over the centuries (a copy or an entire edition): detection of the rarity of an edition or a copy, the reasons for this rarity (censorship, religious persecution, fires, wars or extreme popularity among readers and as a result 'wear and tear', i.e. physical wear and tear of materials, poor condition of copies, etc.), the search for publications known only from the bibliography and attribution of defective copies; the study of 'book-reader' problems, primarily through marginal entries in old books, etc.; the complex examination of private libraries and historical institutions' libraries, which ceased to exist autonomously a long time ago and remained as a part of other, later book collections.

Equally significant are the problems of book preservation, both individual and collections - for certain categories, the requirements for preservation ought to be stricter, given their historical value (stricter accounting of books, requirements for

${ }^{33}$ L. A. Dubrovina, Kodykolohiya ta kodykohrafiya ukrayins'koyi rukopysnoyi knyhy, Kyyiv 1992.

34 Ya. P. Zapasko, Pam'yatky knyzhkovoho mystetstva. Ukrayins'ka rukopysna knyha, L'viv 1995.

35 V. Ya. Frys, Istoriya kyrylychnoyi rukopysnoyi knyhy v Ukrayini X-XVIII st., L’viv 2003. 
temperature, humidity, illumination, safety of book depositories); the digitisation of old copies (introduction of copies into scientific and general circulation through publication in digital libraries) is closely related to the issues mentioned above. Here we should also mention matters of bibliographic registration at the level of the modern electronic catalogue of a particular institution, a broad scientific description in printed catalogues (thematic, chronological and others); problems of consolidated databases catalogues of old prints at the level of a large library, a number of libraries, in a single state register or in a world database.

This whole block of problems related to the history, current state and prospects of continued existence of book memorabilia in public repositories, especially in libraries, we once proposed naming 'book commemoration' ${ }^{36}$ Indeed, if there is a science that studies manuscripts (codicology), incunabula, i.e. first printings printings of the second half of the 15th century (incunabula studies), so why is there no definition of science related to the other old prints, rare and valuable books of the 19th-20th centuries? After all, scientific knowledge and appropriate methods of work in this field do exist, they accumulate and grow. It is not bibliology in its pure form, not the history of the book, not library science, not the bibliography, and not book collecting science, although the achievements of all these sciences are combined here.

As we mentioned before, bibliology detached from the sources - the books themselves (its main object of study), is doomed to decline. Taking this into account, we think that book memorabilia science is a bibliological discipline (according to the main subject of research), along with codicology, editology ${ }^{37}$ (the science of book publishing), bibliopolistics ${ }^{38}$ (the science of the book trade), bibliopegy ${ }^{39}$

${ }^{36}$ H. I. Koval'chuk, Teoriya ta praktyka knyzhkovoho pam'yatkoznavstva XX stolittya. Avtoreferat dysertatsiyi... doktora ist. nauk. 07.00.08 - knyhoznavstvo, bibliotekoznavstvo, bibliohrafoznavstvo, Kyyiv 2005.

37 M. Shatrova, "Edytsiolohiya - dystsyplina knyhoznavchoho tsyklu", Bibliotekoznavstvo. Dokumentoznavstvo. Informolohiya 2011, no 3, pp. 59-62.

38 Eadem, "Nauka pro knyhotorhovel'nu spravu v systemi knyhoznavstva", Visnyk L'vivs'koho universytetu, seriya "Knyhoznavstvo, bibliotekoznavstvo ta informatsiyni tekhnolohiyi” 7, 2012, pp. 117-121; O. V. Antonyk, "Knyhoznavstvo yak systemne znannya pro knyhu i knyzhkovu spravu. Rynkovi mozhlyvosti”, Polihrafiya i vydavnycha sprava 2011, no 1 (53), pp. 3-9.

39 O. M. Hal'chenko, "Bibliopehistyka — spetsial'na istorychna dystsyplina pro istoriyu, tekhniku ta mystetstvo ozdoblennya opravy", [in:] Spetsial'ni istorychni dystsypliny. Pytannya teoriyi ta metodyky, vol. 5, Kyyiv 2000, pp. 313-322; eadem, "Pereplet ukrainskikh rukopisnykh i pervopechatnykh knig. Sovremennoye sostoyaniye izucheniya i dal'neyshiye perspektivy", [in:] Biblioteki natsional'nykh akademiy nauk. Problemy funktsionirovaniya, tendentsii razvitiya, vol. 5, Kiyev 2007, pp. 81-105; eadem, "Atrybutsiya ta vyznachennya pervynnosti opravy pry opysuvanni kyrylychnykh rukopysnykh knyh XVI st. Sposterezhennya kodykoloha”, Rukopysna ta knyzhkova spadshchyna Ukrayiny 17, 2013, pp. 332-335. 
(the science of book binding), book collecting science ${ }^{40}$ (the science of collecting books, private libraries creation), and general bibliology, which studies the structure, terminological apparatus, philosophy of the book, etc. Book memorabilia science is closely connected with the art and history of books, librarianship and bibliography, bibliophilia, filigranology, marginal inscriptions study and other special historical disciplines, as well as with the scientific problems of restoration and conservation of books.

The historical and bibliological approach of research is commonly used in all institutions where significant book funds are collected: VNLU, V. Stefanyk Lviv National Scientific Library, scientific libraries of Odessa, Kharkiv, Lviv, Kyiv and Uzhhorod universities, the Museum of Books and Printing of Ukraine, Kharkiv Korolenko State Scientific Library, Odessa National Scientific Library.

Each of the institutions, despite the same tasks, have their own specifics, due to the certain composition of funds, the traditions of a particular institution, staff and therefore, its scientific school and different results that collectively develop Ukrainian bibliology.

There are higher education institutions that train bibliologists, namely the Ukrainian Academy of Printing (Lviv), Kyiv National University of Culture and Arts, ${ }^{41}$ Rivne State Humanitarian University and Kharkiv Academy of Culture.

At the same time, the use of the term 'history of book culture' has become more frequent in scientific publications. This term has replaced 'history of books' and is in fact a broader concept. In our opinion, the history of book culture is a complex discipline that studies not only the history of book publishing, but also the processes related to the creation and functioning of books in society, depending on the culture of a particular historical period (general and book culture in particular), including editorial culture (completeness of the source information and its placement, presence of prefaces or afterwords in the books, comments on the edges of the book, footers); correction culture; changes in the technology of book production, development of book art (decorations and fonts, culture of their placement on the pages of the book); changes in book formats, choice of paper grades for a particular edition, binding and cover design, etc.

The second block of the 'history of book culture' complex is the culture of books distribution through various forms: the sale of books or their public use in

${ }^{40}$ H. Koval'chuk, "Shcho take bibliofiloznavstvo. Rozdumy shchodo teoriyi bibliofil'stva", [in:] Al'manakh bibliofiliv, comp. Ye. Pshenychnyy, vol. 2, Drohobych 2017, pp. 75-83.

${ }^{41}$ Knyhoznavcha shkola. Antolohiya, uklad. V. M. Medvedyeva, Kyyiv 2016; Knyhoznavcha shkola Kyyivs'koho natsional'noho universytetu kul'tury i mystetstv. Antolohiya, comp. V. M. Medvedyeva, Kyyiv 2018; I. V. Tymoshenko, "Osoblyvosti struktury zahal'noho i spetsial'noho knyhoznavstva", [in:] Naukovi pratsi Natsional'noyi biblioteky Ukrayiny imeni V. I. Vernads'koho, Kyyiv 2007, pp. 651-659. 
libraries (monastery and private libraries, educational institutions, etc.), giving books as gifts to churches, institutions or individuals (records of the first form of ownership inside the books). Scientific catalogues of autographs and bookplates on books became popular. ${ }^{42}$ The culture of consuming books, i.e. reading, collecting, admiring and sometimes even worshipping them, is directly related to book distribution.

It is possible to differentiate the third block as well. It is the culture of book description, traditionally studied within the history of bibliography. But it is impossible to isolate this block comprehensively while ignoring the changes in the culture of registering books in various forms of catalogues, bibliographic lists, changes in bibliographic reference systems and in book advertising.

All the components of book culture that were mentioned or not mentioned above have been changing over time, depending on the development of the production branch associated with the creation of books and publications that contain not only text but also other types of symbolic information: musical notes, maps, images; depending on the development of political and social relations, science and culture (in particular - literature, its various genres and fashion); depending on the state of literacy and education in society, reading and writing skills.

The Institute of Bibliology of the Vernadsky National Library of Ukraine (VNLU) studies the history of book culture in all areas of this complex. The idea and purpose of the study is to generalise the knowledge about the book culture of Ukraine in different chronological periods (16th-20th century) by studying every copy of specialised book funds of the Institute (departments of early printed and rare books, historical collections, fine arts, music), by creating databases and scientific catalogues, preparing articles and bibliographic monographs.

Another area of bibliological research carried out by the Vernadsky National Library of Ukraine is the examination of rare and valuable books. The topicality of such an examination has recently increased significantly due to the recommendations of international cultural heritage organisations, including the questions of 'mankind memorabilia' registration, which is concentrated mainly in books, manuscripts, printed documents, photographs, films and sound recordings. Proper expertise is required to maintain the state register of national cultural heritage, including its integral part "Book memorabilia of Ukraine". Moreover, the opening of borders after the collapse of the USSR and a significant increase in information (including Internet resources) about the cost of early printed and rare books

42 L. M. Denysko, Avtohrafy na knyhakh iz kolektsiyi ridkisnykh vydan' Natsional'noyi biblioteky Ukrayiny imeni V. I. Vernads'koho. Kataloh, Kyyiv 2007; L. M. Denysko, Yu. K. Rudakova, Knyzhkovi znaky na knyhakh iz kolektsiyi ridkisnykh vydan' Natsional'noyi biblioteky Ukrayiny imeni V. I. Vernads'koho. Kataloh, Kyyiv 2017; Knyzhkovi znaky yevropeys'kykh bibliofiliv u kolektsiyakh universytets'koyi biblioteky. Al'bom-kataloh, comp. O. V. Polevshchykova, M. V. Aleksyeyenko, H. V. Velykodna, Odesa 2017. 
at world auctions have contributed to criminal attempts (by wealthy people who invest heavily in forming their own libraries, sometimes not quite legally) to 'redistribute' valuable books. Then again, the proper expertise of valuable books, which are now probably lost to society, is needed. The authentication process also deserves close attention. The forgery cases of texts, publications, autographs have been known as long as since the 18th century and still take place today. As a rule, people try to present later reprints of certain works as the first edition, they correct damaged initial data on the book or even create the title page of the original using modern techniques.

Thus, the bibliologic school of the Vernadsky National Library of Ukraine is distinguished by historical and bibliological research in the field of codicology and codicography, book memorabilia, history of book culture (which includes research of individual and historical library collections) ${ }^{43}$ filigranology, ${ }^{44}$ art of Ukrainian old prints, ${ }^{45}$ scientific fundamentals and methods of rare and valuable publications examination, ${ }^{46}$ culture research of Ukrainian diaspora publications, ${ }^{47}$ etc.

Regarding the prospects for Ukrainian bibliology, we believe that the trends and directions of development mentioned in the article will remain. They will be replenished with new scientific developments in e-books, their interrelation with traditional books, the future of the book, and sciences that study it. As the book in any form continues to function in society, the prospects of bibliology's existence and development are encouraging.

\section{Translated by Kateryna Onoiko-Miller}

${ }^{43}$ L. A. Dubrovina, "Klassifikatsiya i nauchno-informatsionnoye opisaniye kollektsiy i sobraniy v Natsional'noy biblioteke Ukrainy imeni V. I. Vernadskogo", [in:] Biblioteki natsional'nykh akademiy nauk. Problemy funktsionirovaniya, tendentsii razvitiya 5, Kiyev 2007, pp. 58-80; I. O. Tsiborovs'ka-Rymarovych, "Rekonstruktsiya istoriyi ta fondiv rodovykh shlyakhets'kykh bibliotek. Teoretychni ta praktychni aspekty problemy", [in:] Materialy Mizhnarodnoyi naukovoyi konferentsiyi "Istorychni kolektsiyi u knyhozbirnyakh: problemy zberezhennya, vyvchennya, rekonstruktsiyi”, ed. M. O. Podrezova, Odesa 2004, pp. 165-175.

44 N. P. Bondar, "Filihranolohichnyy analiz skhidnoslov"yans'kykh starodrukiv yak dzherelo knyhoznavchykh doslidzhen"”, Rukopysna ta knyzhkova spadshchyna Ukrayiny 14, 2010, pp. 211-264.

45 D. Fomenko, I. Tsynkovs'ka, H. Yukhymets', Midni hraviruval'ni doshky ukrayins'kykh drukaren' XVII-XIX st. u fondakh Natsional'noyi biblioteky Ukrayiny imeni V. I. Vernads'koho, Kyyiv 2014.

46 H. I. Koval'chuk, "Osnovni pidkhody do ekspertyzy knyzhkovykh pam'yatok u bibliotekakh”, [in:] Libri Descripti. Materiały międzynarodowej konferencji naukowej „Opis edycji rzadkich i unikatowych" (Charków, 16-19 września 2013 roku), red. I. Kaczur, M. Romanowska, Kraków 2016, pp. 25-77.

47 T. D. Antonyuk, “Knyhoznavcha kharakterystyka vydan' ukrayins'koyi diaspory ta yikh rol' u konsolidatsiyi ukrayinstva", Bibliotechnyy visnyk 2017, no 6, pp. 18-22. 


\section{BIBLIOGRAPHY}

Andriychuk M. T., "Z istoriyi stanovlennya vitchyznyanoyi knyhoznavchoyi nauky (XIX-pochatok XXI st.)", Tekhnolohiya i tekhnika drukarstva 2016, no 4, pp. 88-111; 2017, no 1, pp. 88-103.

Antonyk O. V., "Knyhoznavstvo yak systemne znannya pro knyhu i knyzhkovu spravu. Rynkovi mozhlyvosti", Polihrafiya i vydavnycha sprava 2011, no 1 (53), pp. 3-9.

Dubrovina L. A., "Klassifikatsiya i nauchno-informatsionnoye opisaniye kollektsiy i sobraniy v Natsional'noy biblioteke Ukrainy imeni V. I. Vernadskogo", [in:] Biblioteki natsional'nykh akademiy nauk. Problemy funktsionirovaniya, tendentsii razvitiya 5, Kiyev 2007, pp. 58-80.

Isayevych Ya. D., "Ukrayins'ke knyhoznavstvo. Etapy rozvytku”, Visnyk L'vivs'koho universytetu. Seriya knyhoznavstvo, bibliotekoznavstvo ta informatsiyni tekhnolohiyi 1, 2006, pp. 7-19.

Koval'chuk G. I., "Istoricheskiye traditsii ukrainskoy knizhnoy kul'tury i ikh issledovaniya", [in:] Kniga. Issledovaniya i materialy, vol. 89, nr 1-2, Moskva 2002, pp. 80-92.

Koval'chuk H., "Knyhoznavstvo ta doslidzhennya istoriyi knyhy v Ukrayini”, [in:] Entsyklopediya istoriyi Ukrayiny, vol. 4, ed. V. A. Smoliy, Kyyiv 2007, pp. 362-363.

Koval'chuk H. I., Osnovni pidkhody do ekspertyzy knyzhkovykh pam'yatok u bibliotekakh, [in:] Libri Descripti. Materiały międzynarodowej konferencji naukowej „Opis edycji rzadkich i unikatowych" (Charków, 16-19 września 2013 roku), red. I. Kaczur, M. Romanowska, Kraków 2016, pp. 25-77.

Koval'chuk H. I., Teoriya ta praktyka knyzhkovoho pam'yatkoznavstva XX stolittya. Avtoreferat dysertatsiyi... doktora ist. nauk. 07.00.08 - knyhoznavstvo, bibliotekoznavstvo, bibliohrafoznavstvo, Kyyiv 2005.

Koval'chuk H. I., Ukrayins'kyy naukovyy instytut knyhoznavstva (1922-1936), Kyyiv 2015.

Lytvynova L. A., Dysertatsiyni doslidzhennya yak dzherelo vyznachennya stanu i tendentsiy rozvytku knyhoznavstva, bibliotekoznavstva, bibliohrafoznavstva v Ukrayini (1994-2012). Avtoreferat dyssertatsyy... kandydata nauk iz sotsial'nykh komunikatsiy, Kyyiv 2013.

Markova V., "Doslidzhennya knyzhkovoyi komunikatsiyi. Semiotychnyy pidkhid", Visnyk Kharkivs'koyi derzhavnoyi akademiyi kul'tury 41, 2013, pp. 187-196.

Markova V., "Knyha v konteksti sotsial'no-komunikatyvnoho pidkhodu. Zdobutky ta perspektywy", Polihrafiya i vydavnycha sprava 2008, no 1, pp. 73-79.

Markova V., Knyha v sotsial'no-komunikatyvnomu prostori. Mynule, suchasne, maybutnye. Monohrafiya, Kharkiv 2010.

Markova V., 'Knyha yak sotsial'no-komunikatyvna model' spryynyattya y reprezentatsiyi real'nosti", Visnyk Knyzhkovoyi palaty 12, 2010, pp. 35-38.

Markova V., "Knyzhkova y elektronna komunikatsiyi. Problemy vzayemovplyvu", Visnyk Kharkivs'koyi derzhavnoyi akademiyi kul'tury, 45, 2014, pp. 70-78.

Markova V., "Metodolohichni zasady vyvchennya knyzhkovoyi komunikatsiyi”, Visnyk Knyzhkovoyi palaty 2014, no 2, pp. 42-44.

Markova V., "Prohnoz shchodo maybutn'oho knyhy", Visnyk Kharkivs'koyi derzhavnoyi akademiyi kul'tury 32, 2011, pp. 207-215.

Nyzovyy M. A., Vstup do knyhoznavstva. Navchal'nyy posibnyk, Kyyiv 2009.

Pastushenko O. V., Knyha i periodyka $v$ dysertatsiynykh doslidzhennyakh nezalezhnoyi Ukrayiny. Sotsiokomunikatsiynyy aspekt. Monohrafiya, Kyyiv 2016.

Shalashna N., "Istoriya knyhy yak nauka v pershiy polovyni XIX st.", Naukovi pratsi Natsional'noyi biblioteky Ukrayiny imeni V. I. Vernads'koho 10, 2003, s. 42-60. 
Shalashna N., "Osoblyvosti rozvytku istoryko-knyhoznavchoyi dumky v Ukrayini v druhiy polovyni XIX st.", Naukovi pratsi Natsional'noyi biblioteky Ukrayiny imeni V. I. Vernads'koho 11, 2003, pp. 398-426.

Shatrova M., "Edytsiolohiya - dystsyplina knyhoznavchoho tsyklu", Bibliotekoznavstvo. Dokumentoznavstvo. Informolohiya 2011, no 3, pp. 59-62.

Shatrova M., "Nauka pro knyhotorhovel'nu spravu v systemi knyhoznavstva", Visnyk L'vivs'koho universytetu. Seriya Knyhoznavstvo, bibliotekoznavstvo ta informatsiyni tekhnolohiyi 7, 2012, pp. 117-121.

Sheyko V., Kushnarenko N., Solyanyk A., "Kharkivs'ka naukova shkola knyhoznavstva, bibliotekoznavstva ta bibliohrafoznavstva: systema komunikatsiynykh zv"yazkiv", Visnyk Knyzhkovoyi palaty 2012, no 11, pp. 40-45.

Shvetsova-Vodka H. M., "Aktual'ni problemy bibliolohiyi”, Visnyk Knyzhkovoyi palaty 2013, no 9, pp. $40-41$.

Shvetsova-Vodka H. M., "Mistse bibliolohiyi v systemi naukovoho znannya", Bibliotechnyy visnyk 2013, no 4, pp. 3-9.

Shvetsova-Vodka H. M., Zahal'na teoriya dokumenta i knyhy. Navchal'nyy posibnyk, Kyyiv 2014.

Shvetsova-Vodka G. N., "Bibliologicheskiye issledovaniya knizhnoy kul'tury", [in:] Sovremennyye problemy knizhnoy kul'tury. Osnovnyye tendentsii i perspektivy razvitiya. Materialy Mezhdunarodnogo nauchnogo seminara (Minsk, 2-3 aprelya 2014 g.), Minsk-Moskva 2014, pp. 59-62.

Shvetsova-Vodka G. N., "Novyye opredeleniya kategorii »kniga«", [in:] Sovremennyye problemy knizhnoy kul'tury. Osnovnyye tendentsii i perespektivy razvitiya. Materialy III i IV Mezhdunarodnykh seminarov, Minsk-Moskva 2015, pp. 121-126.

Shvetsova-Vodka G. N., "Prepodavaniye bibliologii v Ukraine", [in:] Berkovskiye chteniya - 2015. Knizhnaya kul'tura v kontekste mezhdunarodnykh kontaktov. Materialy III Mezhdunarodnoy nauchnoy konferentsii (Minsk, 26-27 maya 2015 g.), Minsk-Moskva 2015, pp. 599-603.

Shvetsova-Vodka G. N., "Sovremennoye sostoyaniye i perspektivy razvitiya bibliologii kak kompleksnoy nauki, posvyashchennoy knizhnoy kul'ture", [in:] Knizhnaya kul'tura. Opyt proshlogo i problemy sovremennosti, Moskva 2015, pp. 388-392.

Tymoshenko I. V., „Osoblyvosti struktury zahal'noho i spetsial'noho knyhoznavstva”, [in:] Naukovi pratsi Natsional'noyi biblioteky Ukrayiny imeni V. I. Vernads'koho, Kyyiv 2007, pp. 651-659.

Tymoshenko I. V., "Ukrayins'ke knyhoznavstvo u 60-70-kh rokakh XX st.”, Bibliotechnyy visnyk 2008, no 5, pp. 17-23.

HALYNA KOVAL'CHUK

\section{BIBLIOLOGY IN MODERN UKRAINE: THE MAIN TRENDS, SCIENTIFIC SCHOOLS, TENDENCIES}

\section{Summary}

In the article the status of Ukrainian bibliological research and its main characteristics throught the last two decades, i.e. since the beginning of the 21 st century, are presented. The main centres, scientific schools, problematics of research, contribution of particular scientists in the 
development of bibliology and certain bibliologic disciplines are defined. The author discusses main trends of bibliological research at the V.I. Vernadsky National Library of Ukraine as a main scientific institution in the field of bibliology and particular bibliologic disciplines: codicology, book monument studies, history of book culture, expertise of rare books, research of historical library collections.

KEY WORDS: Ukrainian bibliology, bibliologic schools, book monument studies, history of book culture, rare books expertise 